J. Perinat. Med. 17 (1989) 231

\title{
The influence of pleural effusion on pulmonary growth in the human \\ The influence of pleural effusion on pulmonary growth in the human
fetus
}

\author{
Hirotaka Maeda', Hiroshi Shimokawa ${ }^{1}$, Yoshiyuki Yamaguchi', Katsuo Sueishi' ${ }^{2}$, and \\ Hitoo Nakano'
}

${ }^{1}$ Department of Gynecology and Obstetrics, ${ }^{2}$ First Department of Pathology, Faculty of Medicine, Kyushu University, Fukuoka, Japan

\section{Introduction}

Pleural effusion in a fetus is readily diagnosed antenatally using ultrasound. It is well known that fetuses with pleural effusion often die of respiratory failure during the neonatal period. We [8] also reported previously that the outcome of fetuses with nonimmunologic hydrops fetalis (NIHF) complicated further by pleural effusion was significantly poor, compared to that in NIHF without pleural effusion, and suggested that the cause of death in fetuses with pleural effusion may be associated with hypoplastic lung.

The possible relation of the cause and effect between pleural effusion and hypoplastic lung, however, remained unclear. The influence of pleural effusion on pulmonary growth in affected fetuses had to be clarified in order to establish proper perinatal management.

In the present study, we attempted to assess the correlation between lung weight and the time of initial diagnosis or the duration of presence of pleural effusion, in order to clarify the influence of pleural effusion on pulmonary growth in the human fetus.

\section{Materials and methods}

Thirty-three fetuses with pleural effusion were diagnosed antenatally, at the Maternity Care Unit of Kyushu University Hospital between January 1983 and March 1988. In 20 out of 33 cases, autopsies were performed and lung weights were measured, the results of which make up this study.

\section{Curriculum vitae}

Hirotaka Maeda, M.D., was born in 1954. He graduated from the Faculty of Medicine, Kyushu University in 1979. He is now a lecturer in the Department of Gynecology and Obstetrics, Faculty of Medicine, Kyushu University. His main field of interest is fetal medicine.

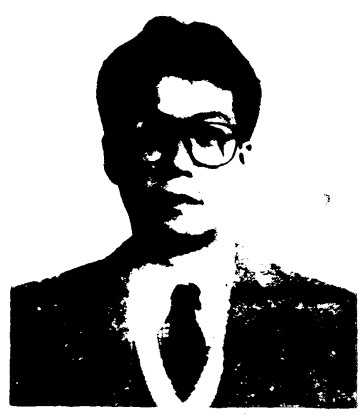

Of the remaining 13 cases, 9 were excluded because of the family's refusal to allow an autopsy and the last 4 cases diagnosed after 30 weeks of gestation survived through to the time of this writing. Drainage of pleural effusion, on a continuous basis, from the thoracic cage in utero, was not performed on any of these cases.

Wet weight measured at autopsy was used as the weight for each organ. In order to evaluate pulmonary growth, the lung weight/body weight ratio and the standard deviation from the mean normal weight at each gestational age was used $[5,7]$. The normal standard of body and organ weights used was that reported by GRUENWALD et al [3].

Information concerning the time of initial diagnosis and delivery, along with the findings at autopsy, were obtained from medical records kept in our hospital.

Statistical analysis was performed using the chisquare test, and a p-value of less than 0.05 was regarded as being statistically significant. 


\section{Results}

Underlying diseases and lung weights of the twenty cases studied are shown in table I.

Gestational age at the time of initial diagnosis ranged from 21 to 35 weeks, and the time of delivery ranged from 23 to 36 weeks of gestation. The time between the initial diagnosis and delivery ranged in duration from 5 days to 8 weeks.

Lung weights ranged from 1.8 to 33.0 grams, and the lung weight/body weight ratio was less than $0.020[5,7]$ in all cases. The distribution of the standard deviation from the mean weight for the body, heart, liver and lungs is shown in figure 1. Body weights were within the mean $\pm 1.5 \mathrm{~S}$. D. in 11 of 20 cases, more than +1.5 S.D. in eight cases and less than $-1.5 \mathrm{~S}$. D. in one case. Heart weights were within the mean $\pm 1.5 \mathrm{~S}$. D. in 16 of 20 cases, more than $+1.5 \mathrm{~S}$. D. in two cases and less than $-1.5 \mathrm{~S}$. D. in two cases. Liver weights were within the mean $\pm 1.5 \mathrm{~S}$. D. in 17 of 20 cases and less than $-1.5 \mathrm{~S}$. D. in three cases. Lung weights were within the mean $\pm 1.5 \mathrm{~S}$. D. in eight of 20 cases, and less than $-1.5 \mathrm{~S}$. D. in 12 cases. The rate of incidence of cases with weights less than $-1.5 \mathrm{~S}$. D. in body, heart, liver and lungs is $5.0 \%, 10.0 \%, 15.0 \%$ and $60.0 \%$, respectively. The incidence of cases with lung weights less than -1.5 S. D. was significantly higher than the incidence of cases with weights of less than -1.5 S.D. for other organs in cases with pleural effusion $(\mathrm{p}<0.01)$.

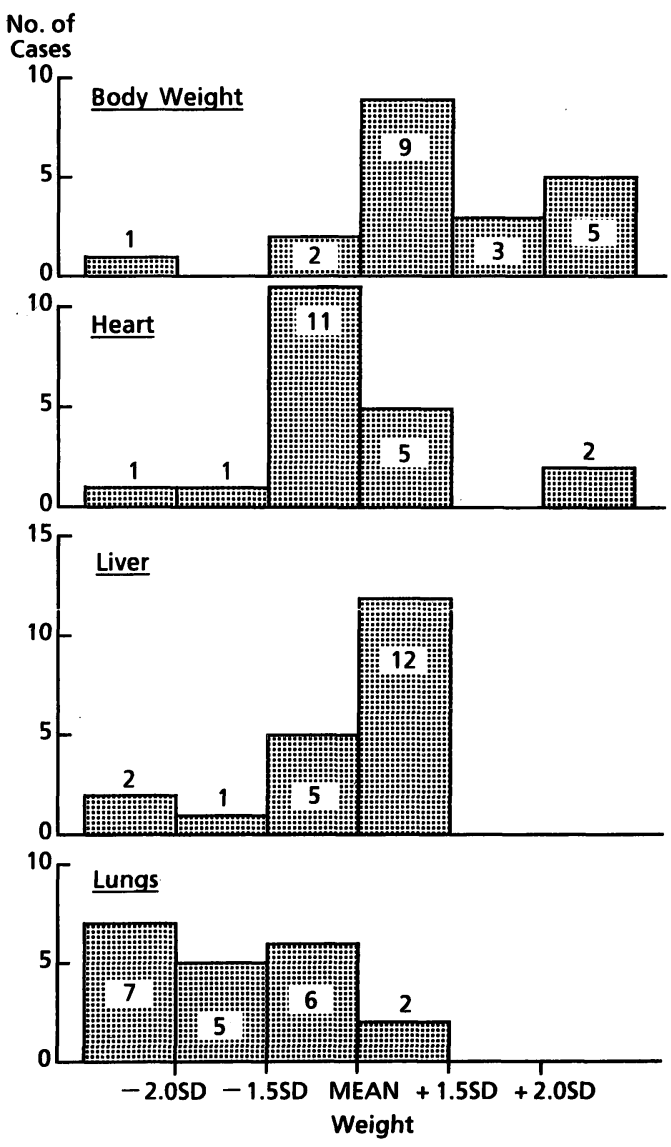

Figure 1. Body and organs weights in 20 cases affected with NIHF with pleural effusion. Weights are expressed in the form of the standard deviation from the mean weight at each gestational age.

Table I. Underlying diseases and lung weights of 20 cases with pleural effusion

\begin{tabular}{|c|c|c|c|c|}
\hline \multirow[t]{2}{*}{ Underlying disease } & \multirow{2}{*}{$\begin{array}{l}\text { No. of } \\
\text { cases }\end{array}$} & \multicolumn{3}{|c|}{ Lung Weight } \\
\hline & & $\begin{array}{l}\text { Mean } \\
\pm 1.5 \mathrm{SD}\end{array}$ & $<-1.5 \mathrm{SD}$ & $<-2.0 \mathrm{SD}$ \\
\hline Coarctation of the aorta & 1 & & 1 & \\
\hline $\mathrm{T} / \mathrm{F}^{*}+\mathrm{ASD}^{* *}$ & 1 & 1 & & \\
\hline Premature closure of foramen ovale & 1 & & & 1 \\
\hline Hypertrophy of bilateral ventricles & 1 & 1 & & \\
\hline Nuchal hygroma & 1 & & & 1 \\
\hline Cystic adenomatoid malformation of the lung & 2 & 1 & 1 & \\
\hline Trisomy 21 & 2 & & 2 & \\
\hline Human Parvo virus B-19 infection & 3 & 1 & 1 & 1 \\
\hline Idiopathic hydrops fetalis & 8 & 4 & & 4 \\
\hline Total & 20 & 8 & 5 & 7 \\
\hline
\end{tabular}

*T/F: tetralogy of Fallot, **ASD: Atrial septal defect 
The correlation between the time of initial diagnosis and lung weight is shown in figure 2. In all the cases with lung weights of less than $-2.0 \mathrm{~S}$. D., pleural effusion was diagnosed during the first 29 weeks of gestation. However, when the incidence of lung weights of less than $-1.5 \mathrm{~S}$. D. or -2.0 S. D. was compared by gestational age from 22 to 34 weeks, there were no statistical significant differences.

With regard to the correlation between the duration of the presence of pleural effusion and lung weight, the shortest duration showing a statistically significant difference obtained in the incidence of lung weights of less than $-1.5 \mathrm{~S}$. D. or $-2.0 \mathrm{~S}$. D., was two weeks. In six cases with a duration of less than two weeks, lung weights were within the mean $\pm 1.5 \mathrm{~S}$. D. On the contrary, in 14 cases having a duration of more than two weeks, lung weights were less than $-1.5 \mathrm{~S}$. D. in 12 cases $(85.7 \%)$, and less than $-2.0 \mathrm{~S}$. D. in seven cases $(50.0 \%)$ (figure 3 ). The incidence of cases with lung weights of less than $-1.5 \mathrm{~S}$. D. or -2.0 S. D. significantly increased in situations where the duration of pleural effusion was more than two weeks, compared to those cases in which the duration was less than two weeks $(p<0.01$, $\mathrm{p}<0.05$, respectively).

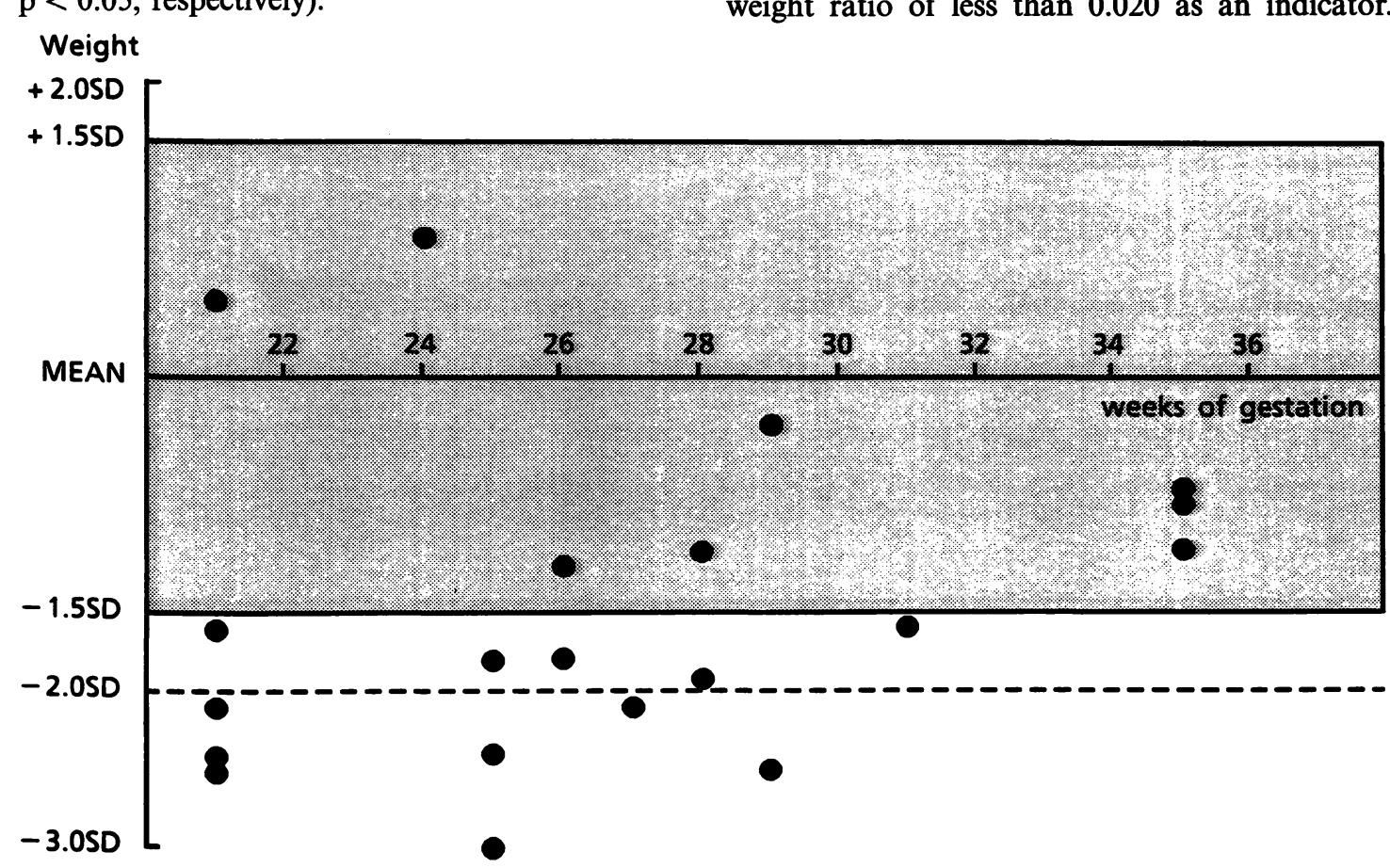

Figure 2. The correlation between the time of initial diagnosis and lung weight. Weights are expressed in the form of the standard deviation from the mean weight at each gestational age.

\section{Discussion}

Pleural effusion in a fetus, theoretically, can inhibit pulmonary growth by increasing intrathoracic pressure. However, the relation of cause and effect between persistent pleural effusion and the development of hypoplastic lung has not been proven in human subjects.

Castillo et al [1], and Shimokawa et al [9] reported that the outcome of nonimmunologic hydrops fetalis (NIHF) with pleural effusion is significantly poor, compared to that of NIHF without pleural effusion, and suggested that the cause of death may be associated with the coexistence of hypoplastic lung. CASTILLo et al [2] reported that normal lung development was disturbed in 9 cases of NIHF with pleural effusion, using histological examination. In the present study, 12 of 20 cases had lung weights of less than $-1.5 \mathrm{~S}$. D. and 7 cases had lung weights of less than $-2.0 \mathrm{~S}$. D. This evidence indicates that persistent pleural effusion often coexists with the inhibition of pulmonary growth in the fetus, irrespective of underlying diseases the fetus may have.

With regard to the definition of hypoplastic lung, REALE et al [7] proposed a lung weight/body weight ratio of less than 0.020 as an indicator. 


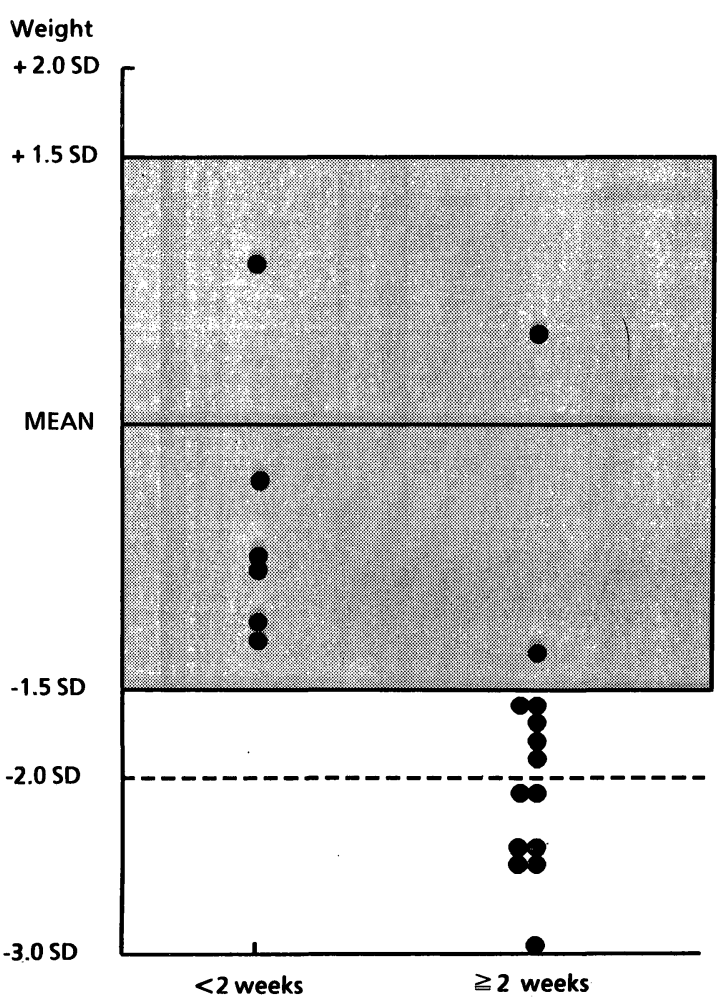

Figure 3. The correlation between the duration of the presence of pleural effusion and lung weight. Weights are expressed in the form of the standard deviation from the mean weight at each gestational age.

NimRoD et al [5] proposed both a lung weight/ body weight ratio of less than 0.020 and a lung weight of less than $-2.0 \mathrm{~S}$. D. as the indicator of hypoplastic lung. For evaluating the hypoplastic lung in NIHF, the criteria of NIMROD et al [5] seems to be better than that of REALE et al [7], because body weight in NIHF may be heavy due to the accumulation of ascites or pleural effusion. In the present study, the lung weight/body weight ratio was less than 0.020 in all cases, but lung weights of less than $-2.0 \mathrm{~S}$. D. were found in only seven of 20 cases. These results indicate that a fetus with pleural effusion does not always have hypoplastic lung. In this study, all seven cases with hypoplastic lung as defined by the criteria of NiMROD et al [5] had a duration of persistent pleural effusion of more than two weeks. On the contrary, in the six cases, with a duration of less than two weeks, lung weights were within the mean \pm 1.5 S.D. This fact suggests that pulmonary growth may not be inhibited if the duration of persistent pleural effusion is less than two weeks, and indicates that the development of pulmonary hypoplasia in a fetus with pleural effusion depends on the duration of the pleural effusion.

In addition, the time of onset of pleural effusion may also influences pulmonary growth in the fetus. The structural development of the human fetal lung has been divided into the following four stages [4]; 1) the embryonic stage, 2) the pseudoglandular stage, 3) the canalicular stage and 4) the alveolar stage. The earlier the gestational age at the onset of pleural effusion, the stronger the influence on pulmonary development may be. CASTILlo et al [2] suggested that significant fluid : accumulation in the pleural space prior to the alveolar stage could cause inevitable damage to the developing lung in a fetus. NimRoD et al [6] reported that, in fetuses with premature rupture of membrane, the risk of developing pulmonary hypoplasia was significantly higher in fetuses with rupture of membranes before 26 weeks of gestation, compared to that of fetuses with a rupture of membrane after 26 weeks of gestation. Although, in the present study, the time of onset of pleural effusion could not be diagnosed accurately, the time of diagnosis was before 29 weeks of gestation in all the cases with lung weights of less than $-2.0 \mathrm{~S}$. D. With regard to the relation between time of diagnosis and lung weight, however, there was no statistical significant difference in the incidence of lung weights of less than $-1.5 \mathrm{~S}$. D. or $-2.0 \mathrm{~S}$. D. among the gestational age groups divided by one-week intervals, ranging from 22 to 34 weeks. Further investigation is necessary to clarify the correlation between the time of onset of pleural effusion and the development of pulmonary hypoplasia.

In conclusion, the findings indicate that persistent pleural effusion in a fetus can inhibit pulmonary growth, and that the development of hypoplastic lung in fetuses with pleural effusion depends on the length of the presence of pleural effusion. In addition, the results also suggest that pulmonary growth may not be influenced by persistent pleural effusion of less than two weeks. Therefore, pulmonary hypoplasia in a fetus with pleural effusion may be prevented by continuous removal of pleural effusion using an effective drain in utero. 


\begin{abstract}
The present study was performed to clarify the relation of cause and effect between pleural effusion and hypoplastic lung in the human fetus. In six cases with a duration of less than two weeks between the initial diagnosis of pleural effusion and delivery, lung weights were within the mean weight $\pm 1.5 \mathrm{~S}$. D. In fourteen cases with a duration of more than two weeks between diagnosis and delivery, seven cases had lungs with weights of less than $-2.0 \mathrm{~S}$. D. and twelve had lungs of
\end{abstract}

Keywords: Fetus, hypoplastic lung, pleural effusion. less than $-1.5 \mathrm{~S}$. D. in weight. The incidence of lung weights less than $-1.5 \mathrm{~S}$. D. or $-2.0 \mathrm{~S}$. D. was significantly higher in cases with a diagnosis-delivery duration of more than two weeks, compared to those with a duration of less than two weeks. These results suggest that the development of hypoplastic lung in fetuses with pleural effusion may depend on the length of the presence of pleural effusion.

\section{Zusammenfassung}

Einfluß eines Pleuraergusses auf das Lungenwachstum beim menschlichen Feten

Um den Einfluß eines Pleuraergusses auf das Lungenwachstum beim menschlichen Feten zu erfassen, versuchten wir in der vorliegenden Studie die Korrelation zwischen dem fetalen Lungengewicht und dem Auftreten bzw. der Dauer eines Pleuraergusses zu bestimmen. Bei 20 Feten mit einem pränatal diagnostizierten Pleuraerguß wurden Autopsien durchgeführt und die Lungengewichte gemessen. Sie lagen zwischen 1.8 und 33.0 Gramm. Die Ratio Lungengewicht/Körpergewicht war in allen Fällen < 0.020. Im Hinblick auf eine Korrelation zwischen der Erstdiagnose eines Pleuraergusses und dem Lungengewicht fanden wir folgendes: zwischen 22 und 34 Gestationswochen kommen Lungengewichte von mehr als 1.5 oder 2.0 Standardabweichungen unterhalb des Mittels statistisch gleich häufig vor. Nimmt man jedoch die Dauer eines Pleuraergusses und korreliert sie mit dem Lungengewicht, so ergibt sich folgendes Bild:

in 6 Fällen, wo der Erguß weniger als zwei Wochen bestand, lagen die Lungengewichte innerhalb von \pm 1.5 Standardabweichungen. Bestand der Erguß jedoch länger als zwei Wochen, wie in 14 Fällen, so lagen in 12 Fällen $(85,7 \%)$ die Lungengewichte um 1.5 Standardabweichungen und in 7 Fällen $(50.0 \%)$ um 2.0 Standardabweichungen unter dem Mittel. Die Inzidenz von Lungengewichten von mehr als 1.5 oder 2.0 Standardabweichungen unterhalb des statistischen Mittels nahm also in den Fällen, wo der Pleuraerguß länger als zwei Wochen bestand, signifikant gegenüber den Fällen zu, wo der Erguß weniger als zwei Wochen vorlag $(p<0.01$ bzw. $p<0.05$ ). Diese Ergebnisse weisen darauf hin, daß ein persistirender Pleuraerguß das Lungenwachstum hemmen kann und daß die Entwicklung von hypoplastischen Lungen bei Feten mit Pleuraerguß abhängig ist von der Dauer des Ergusses. Auf der anderen Seite scheint ein Pleuraerguß, der weniger als zwei Wochen besteht, das Lungenwachstum nicht zu beeinflussen.

Schlüsselwörter: Fet, hypoplastische Lungen, Pleuraerguß.

\section{Résumé}

Influence de l'épanchement pleural sur la croissance pulmonaire chez le fetus humain

Dans cette étude, afin de clarifier l'influence de l'épanchement pleural sur la croissance pulmonaire chez le fotus humain, nous avons essayé d'estimer la corrélation entre le poids pulmonaire fotal et le moment du diagnostic initial d'épanchement pleural ou la durée de l'existence de l'épanchement pleural. Nous avons réalisé des autopsies avec détermination des poids des poumons chez 20 fætus chez lesquels le diagnostic d'épanchement pleural avait été porté en prénatal. Les poids des poumons vont de 1,8 à 33 grammes et le ratio poids pulmonaire/poids corporel est inférieur à 0,020 dans tous les cas. Nous n'avons pas trouvé de différence statistiquement significative en ce qui concerne la corrélation entre le moment du diagnostic initial et le poids pulmonaire, si l'incidence des poids pulmonaires inférieurs à $-1,5$ DS ou -2 DS est rapporté à l'âge gestationnel de 22 à 34 semaines. Néanmoins, en ce qui concerne la corrélation entre les poids pulmonaires et la durée de la présence de l'épanchement pleural, les poids pulmonaires se situaient dans la moyenne + ou $-1,5$ DS, dans six cas avec une durée de moins de 2 semaines. A l'inverse, dans 14 cas avec une durée de plus de 2 semaines, les poids pulmonaires étaient inférieurs à $-1,5 \mathrm{DS}$, dans 12 cas $(85,7 \%)$ et inférieurs à -2 DS dans 7 cas $(50 \%)$. L'incidence des cas avec poids pulmonaires inférieurs à $-1,5$ DS ou -2 DS est significativement augmentée dans les situations où on a trouvé que la durée de l'épanchement pleural était supérieure à 2 semaines, par rapport aux cas pour lesquels la durée de l'épanchement pleural était inférieur à 2 semaines (respectivement $\mathrm{p}<0,01, \mathrm{p}<0,05)$. Ces données indiquent que la persistance d'un épanchement pleural peut inhiber la crois- 
sance pulmonaire et aue l'apparition d'une hypoplasie pulmonaire chez les fætus porteurs d'un épanchement pleural dépend de la durée de la présence de l'épanche- ment. En outre, les résultats suggèrent également que la croissance pulmonaire peut ne pas être influencée par un épanchement pleural de moins de deux semaines.

Mots-clés: Epanchement pleural, fœetus, poumon hypoplasique.

Acknowledgements: We thank Professor K. Ueda, Dr. J. Kukita and the Department of Pediatrics, Kyushu University, for their thoughtful co-operation; the authors also thank L. SAZA for critical reading of the manuscript.

This study was supported by a Grant-in-Aid from the Ministry of Health and Welfare, Japan.

\section{References}

[1] Castillo RA, LD Devoe, HA Hadi, S Martin, D GeIST: Nonimmune hydrops fetalis: Clinical experience and factors related to a poor outcome. Am J Obstet Gynecol 155 (1986) 812

[2] Castillo RA, LD Devoe, G Falls, GB Holzman, HA HADI, HE FADEL: Pleural effusions and pulmonary hypoplasia: Am J Obstet Gynecol 157 (1987) 1252

[3] GRUNenwald P, NH MinH: Evaluation of body and organ weights in perinatal pathology. I. Normal standards deviated from autopsies. Am J Clin Patho 34 (1960) 247

[4] Inselman LS, Mellins RB: Medical progress: Growth and development of the lung. J Pediatr 98 (1981) 1

[5] NimRod C, S Nicholson, D Davis, J Harder, G DoDd, R SAUVE: Pulmonary hypoplasia testing in clinical obstetrics. Am J Obstet Gynecol 158 (1988) 277

[6] Nimrod C, FV Gittings, G Machin, D Campbell, $R$ WESENBERG: The effect of very prolonged membrane rupture on fetal development. Am J Obstet Gynecol 148 (1984) 540
[7] Reale FR, JR Esterly: Pulmonary hypoplasia: a morphometric study of the lungs of infants with diaphragmatic hermia, anencephaly, and renal malformations. Pediatrics 51 (1973) 91

[8] Shimokawa H, K Hara, T Koyanagi, T Hirakawa, E HoRI, H MAEDA, H NAKANO: Intrauterine treatment of nonimmunologic hydrops fetalis associated with pleural effusion. Acta Obst Gynaec Jpn 37 (1985) 66

[9] Shimokawa H, K Hara, H Maeda, S Miyamoto, T KoYANAGI, H NAKANO: Intrauterine treatment of idiopathic hydrops fetalis. J Perinat Med 16 (1988) 133

Received February 20, 1989. Accepted March 6, 1989.

Hiroshi Shimokawa, M. D.

Dept of Gyn/Ob

Faculty of Medicine

Kyushu University 60

Maidashi 3-1-1, Higashi-ku

Fukuoka 812, Japan 